\title{
ONE HEALTH - CONCEPT FOR TODAY AND TOMORROW
}

Sara Savić ${ }^{{ }^{*}}$, Branka Vidić ${ }^{1}$, Miroslav Ćirković ${ }^{1}$, Tamaš Petrović ${ }^{1}$, Tamara Bošković ${ }^{2}$ Dejan Bugarski², Ljiljana Trajković-Pavlovićs Aleksandar Potkonjak ${ }^{4}$, Vuk Vračar, Eldon Uhlenhopp ${ }^{5}$

${ }^{1}$ Scientific Veterinary Institute „Novi Sad“, Novi Sad, Serbia

${ }^{2}$ Ministry of agriculture and environment protection of Republic of Serbia, Veterinary Directorate, Belgrade, Serbia

${ }^{3}$ Institute of public health of Vojvodina, Novi Sad, Serbia

${ }^{4}$ Department of veterinary medicine, Faculty of Agriculture, Novi Sad, Serbia

${ }^{5}$ College for veterinary medicine, University of Iowa, USA

\section{Abstract}

"One Health" has been defined as "the collaborative effort of multiple disciplines - working locally, nationally, and globally - to attain optimal health for people, animals and the environment". One Health is a new initiative, but with the concept that extends back to ancient times. One Health is an interdisciplinary concept for complex health challenges from a holistic integrated perspective, more then a divided perspective based on different disciplines. There is no isolation, wild animals, domestic animals, pathogens and diseases do not know of the political borders. The aim of the One Health initiative is to form unified solutions applicable for the improvement of health of humans, animals and the environment. A workshop was organized for the representatives of all structures and levels of medical and veterinary services of Serbia. During four tasks, among joint working groups, the most important structure of One Health was proposed, introducing possible concept in Serbia.

Key Words: One health, concept, infectious diseases

${ }^{1 *}$ Corresponding author: sara@niv.ns.ac.rs 


\section{JEDINSTVENO ZDRAVLJE - KONCEPT SADAŠNJOSTI I BUDUĆNOSTI}

Sara Savić ${ }^{1}$, Branka Vidić ${ }^{1}$, Miroslav Ćirković ${ }^{1}$, Tamš Petrović ${ }^{1}$,

Tamara Boškovićn , Dejan Bugarski², Ljiljana Trajković-

Pavlović $^{3}$, Aleksandar Potkonjak ${ }^{4}$, Eldon Uhlenhopp ${ }^{5}$

${ }^{1}$ Naučni institut za veterinarstvo „Novi Sad“, Novi Sad

${ }^{2}$ Ministarstvo poljoprivrede i zaštite životne sredine Republike Srbije, Beograd

${ }^{3}$ Institut za javno zdravlje Vojvodine, Novi Sad

${ }^{4}$ Poljoprivredni fakultet,Departman za veterinarsku medicinu, Novi Sad

${ }^{5}$ Fakultet veterinarske medicine, Univerzitet u Ajovi, USA

\section{Kratak sadržaj}

Definiciju i osnovnu suštinu “jedinstvenog zdravlja” predstavljaju "zajednički napori više različitih disciplina, koje rade na lokalnom, nacionalnom i globalnom nivou, da bi se postiglo optimalno zdravlje ljudi, životinja i ekosistema, odnosno životne sredine”. Jedinstveno zdravlje je nova inicijativa, ali koncept ovakvog razmišljanja datira odavno. Jedinstveno zdravlje je interdisciplinaran koncept za složene promene u javnom zdravlju, sa holističkim integralnim pristupom, koji se bazira na različitim naučno-stručnim disciplinama. Kada je u pitanju javno zdravlje, ne postoji mogućnost razdvajanja populacije, divljih i domaćih životinja, uzročnika (patogena) i bolesti, jer oni ne poznaju administrativne političke granice i ograničenja. Cilj inicijative Jedinstvenog zdravlja je da se formiraju jednoobrazna rešenja koja bi se koristila za unapređenje zdravlja ljudi, životinja i životne sredine. Ministarstvo poljoprivrede SAD (USDA) organizovalo je radionicu o Jedinstvenom zdravlju za predstavnike svih struktura i nivoa zdravstvenih i veterinarskih službi u Srbiji. Tokom rada, zajedničke radne grupe, sačinjene od predstavnika pomenutih službi, su kroz četiri zadatka predložile najvažniju strukturu Jedinstvenog zdravljasa ciljem uvođenja mogućeg koncepta “jedinstvenog zdravlja”u Srbiji. Rešavanjem pitanja organizacije i rukovodstva, službene komunikacije, potrebnih izvora finansiranja i merenja uticaja predstvljena je najvažnija struktura “jedinstvenog zdravlja”.

Klučne reči: “jedinstveno zdravlje”, koncept, infektivna oboljenja

\section{INTRODUCTION}

"One Health" has been defined as "The collaborative effort of multiple dis- 
ciplines - working locally, nationally, and globally - to attain optimal health for people, animals and the environment". One Health is a new initiative, yet with the concept that extends back to ancient times. One health initiatives from the past are many. Various emerging health issues are linked to increasing contact between humans and animals, intensification and integration of food production, and the expansion of international travel (Anonymous, 1999). As the number of new infectious diseases emerged in the 20th century, the scientists began to recognize the challenges that societies face regarding these threats that largely come from animals. Of the 1,415 microbes that are known to infect humans, 61 percent come from animals (Taylor et al, 2001).

The 1999 West Nile virus outbreak in New York City highlighted the links between human and animal health. In this outbreak, wild crows began dying about a month before the first human cases were identified. The simultaneous outbreaks were not recognized as caused by the same entity until Dr. Tracey McNamara, an astute veterinarian at the Bronx Zoo, tied them together when her exotic birds began getting sick (Drexler, 2002). After recognizing that the outbreaks were caused by West Nile virus, a new entity in the Western Hemisphere, the Centre of Disease Control (CDC), established the National Centre for Zoonotic, Vector-Borne, and Enteric Diseases, now called the National Centre for Emerging and Zoonotic Infectious Diseases (Anonymous, 2011).

More recently, in 2003, there was a hemorrhagic fever outbreak, when a doctor of veterinary medicine said "Health of people, domestic or wild animals cannot be looked into separately. There is only one health and the solutions demand joint work of all of us on different levels". This veterinarian was William B. Karesh, who later on gave series of lectures, with his colleagues on a topic One World-One Health (Karesh and Cook, 2005).

The avian influenza (HPAI H5N1) epidemic that began in Hong Kong in 1997, forced the global community to recognize that animal health and human health are linked. The 1997 outbreak affected 18 people, killed 6, and provoked the culling of 1.5 million birds. The HPAI H5N1 virus resurfaced in isolated outbreaks between 1998 and 2003. The idea of „One Health" as it became known would assume urgent practical significance in late 2003 with the emergence of highly pathogenic avian influenza (Anonymous, 2010). The World Bank has published a list of steps that should be taken in order to implement the principles of One Health, based on pandemic zoonozes. Of course, non-infectious diseases, which affect local and national communities, should also be taken into consideration. First step includes a leader with an authority, champions in the country, mandatory legislation (reporting on diseases, joint decision making) and naming the priorities. Next step includes the frame for 
collaboration and communication (memorandum of agreement, joint work groups, permanent teams and partial integration of the services). Step 3 includes incentives (joint budget, special grants) and joint systems (diagnostics and monitoring). The last step includes joint communication, integrative subjects (at Universities on human health, animal health and healthy ecosystem). In order to increase the possibility of success of „One Health"initiative, a long term approach, based on risk analysis, is essential. Moreover, a capacity building in all sectors involved in health issues is needed. In addition, understanding between the sectors, which will consequently improve the collaboration and coordination between them is definitely necessary. With the increase of knowledge, all of this could be possible.

One Health is an interdisciplinary concept for complex health challenges from a holistic integrated perspective, more then a divided perspective based on different disciplines. There is no isolation - wild animals, domestic animals, pathogens and diseases do not know of the political borders. The aim of the One Health initiative is to find unified solutions for the use of the health of people, animals and environment. New technologies such as internet (social networks) and mobile phones are valuable tools to successfully support this initiative in promoting and spreading information worldwide. Picture 1 shows a very simple schematic structure of One Health concept.

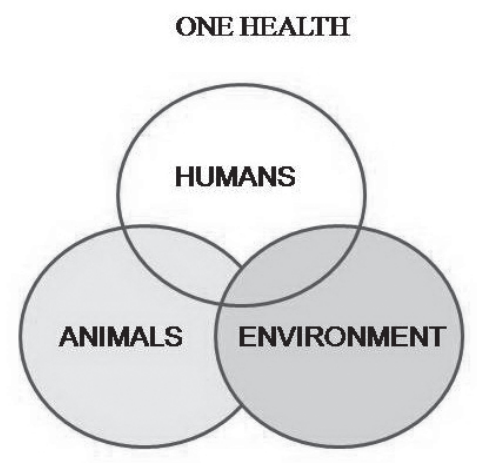

Picture 1 - Schematic view of One Health concept

The principals of One Health initiative demands purposeful and systematic channels of communication between the services for health protection of people, wild and domestic animals. Maybe the best definition of One Health concept, that was already mentioned in he beginning of this article, was given by the working group of American veterinary association in 2008, as a ,joint 
collaboration of more disciplines on local, national and global level, with the aim of reaching optimal health of people, animals and the environment". In 2010, European Union has published a report named „Estimation of the influence and result of global response to the crisis of avian influence". In this report, it is stated: "EU has already undertaken new initiatives under One $\mathrm{He}$ alth initiative and will continue with actions like this in the future". This report highlights the need for the concept of One Health to be transferred into a practical politics and strategy, which will promote the collaboration between agencies and sectors. OIE also supports the One Health approach as common and comprehensive way of handling with the protection of public health and animal health on a global level. This collaboration should not be limited to an international level, but should be transferred as new and fundamental paradigm into all national levels.

The society has came to the moment when priorities and values have changed: Increased risks for public health; Increased expectations from the public; Increased expenses of the interventions; Increased expenses of technology; Decreased influence; Decreased institutional funds; Decreased human resources. The change of view towards One Health concept demands the existence of a vision, identification of a leadership with a relevant body in charge, thus the vision can evolve. To ensure the real upstart of One Health concept, the following parties should be involved: Government, Society, Educators and NGO's, which will have a mutual planning, leadership, financing, partaking and communication (Uhlenhopp, 2014).

Zoonotic diseases are caused by pathogens that can infect both animals and humans, resulting in disease outbreaks, including epidemics in humans and epizootics in animals. These diseases account for 70 percent of emerging infectious diseases. In the absence of timely disease control, zoonotic pathogens can cause pandemics, with potentially catastrophic impacts that are global in scale. Control of a zoonosis requires early and rapid actions. A typical episode may involve a pathogen that originates in wildlife, then passes to livestock, and is then transmitted from livestock to humans. The exposure to a pathogen in animals could be followed by symptoms in animals. Then, an increase of exposure becomes evident in humans, who subsequently could develop symptoms and may seek treatment. The risks of the appearance of food borne diseases differ in the opinion of the experts and in the opinion of the citizens. The experts see the risk in microorganisms, nutrients, contaminants of the environment, natural toxins, and chemicals in agriculture. The citizens on the other hand see the risk of food borne diseases in pesticides, new chemicals in food, additives, fat and cholesterol, and microorganisms (Trajković-Pavlović, 2014). 


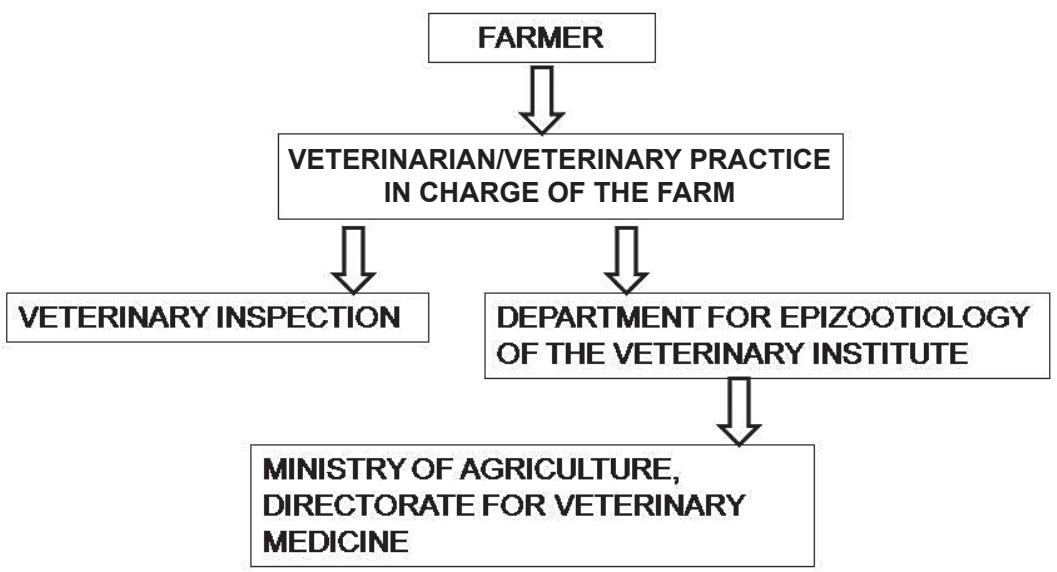

Picture 2 - Diagram of data collection in cases of zoonotic food borne diseases in animals for food production (Law of veterinary medicine, Official Gazette RS 91/2005)

\section{MATERIAL AND METHODS}

The workshop was organized by the US Department of Agriculture (USDA) with the support of American Embassy in March 2014, for the representatives of all structures and levels of medical and veterinary services of Serbia. During joint work of the groups, four tasks were given to the workgroups in order to form a concept of One Health initiative, which could be implemented into the system of supervision and surveillance of public health in Serbia. The aims of the workshop were to increase the awareness of global One Health, to develop understanding of the terminology of One Health, to participate in a dialog about the strategies of implementation, to identify the resources for the implementation of One Health (national and international) and to identify the possibilities and obstacles for implementation of One health in Serbia.

\section{RESULTS AND DISCUSSION}

One of the main results of the workshop was an increased dialog among the resources, sectors and individuals representing different disciplines and services. An improved support for the inter-resource community was gained. Suggested model for the implementation of One Health concept in Serbia was developed. Future possibilities for aiding Ministry of Agriculture were identified.

Currently, the supervision and control of zoonozes within our country is divided between the Ministry of Health (in charge of public health) and Mini- 
stry of Agriculture, Veterinary Directorate (in charge of zoonoses in animals). These two Ministries have all the needed services, resources, people and information, but there is not enough dialogue and information exchange. Different actions and procedures have already been done by a One Health approach (in detection and control of zoonotic epidemics among humans or animals - Q fever, West Nile, Avian influenza), through the initiatives of separate services, or by the departments of the Ministries. Their obligations and duties in correlation to One Health approach should be within the system. There is still room for improvement of mutual collaboration, communication and synchronization of activities within the system. Thus, the proposal of workshop groups was to form a new national body (sector, service), formed of experts, which would be responsible for collecting information, sharing information, communicating and initiating collaboration between Ministries, inspections and other services among different Ministries. Picture 2 shows a draft of possible organization of One Health body with in the existing system.

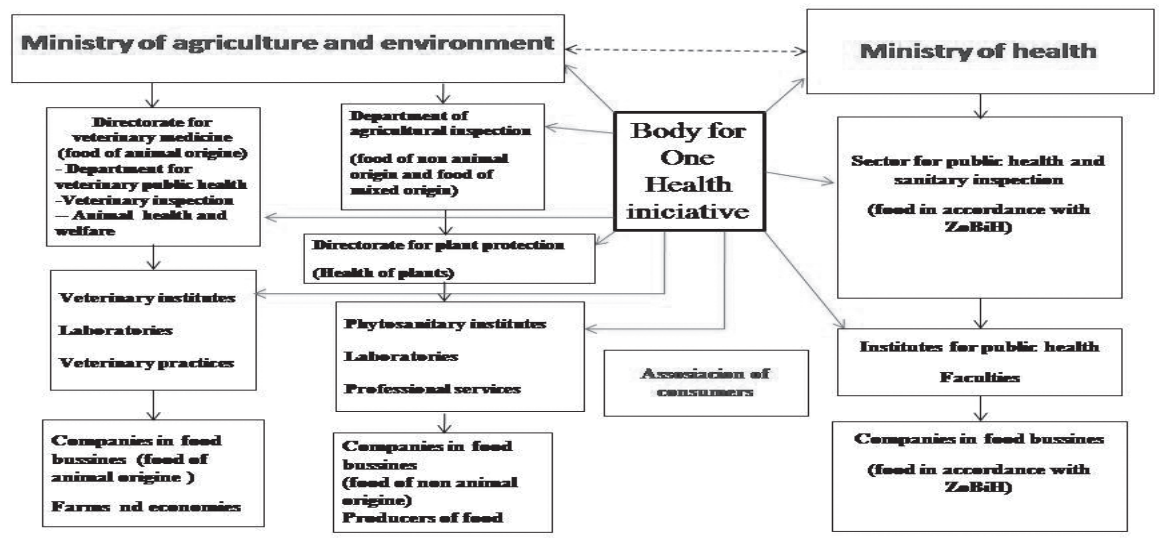

Picture 3 - A proposal of possible organization of the Body for One health initiative within the existing system in Serbia

The organizational challenges, actions of the highest priority, the most important issues and responsible entities were identified. Way of communication through the One Health body was recognized, but also directly, between the institutions and services, depending on weather a question is a matter of internal or external. The ways of financing the resources of the Body for One health approach were proposed, with emphasis on who is in charge for this 
component, who are the users, available funds, additional ways of financing and identifying the final point. In addition, the benefit for the society and public health was recognized, as it would lead to improved public health with less people being on sick leaves, less number of annual incidences, less time spent in hospitals, lower risk from zoonoses, that is, less overall expenses. This would lead to an improvement of capacities for disease control, diagnostics and reduction of their influence to the society.

\section{CONCLUSION}

The development of society in the Republic of Serbia is prepared for the implementation of One Health concept. There are resources (in view of experts and services) for launching the initial organization of One Health approach for Serbia, but there is a need for expanded.

\section{AKNOWLEDGMENTS}

This work is conducted within the project TR31084 funded by the Serbian Ministry of Education, Science and Technological Development

\section{REFERENCES}

1. 1. Taylor LH, Latham SM, Woolhouse ME.: "Risk Factors for Human Disease Emergence." Philos Trans R Soc Lond B Biol Sci July 29, 356, 1411, 983-989, 2001.

2. Taylor LH, Latham SM, Woolhouse ME (July 2001). "Risk factors for human disease emergence". Philos. Trans. R. Soc. Lond., B, Biol. Sci. 356 (1411): 983-9. doi: 10.1098/rstb.2001.0888. PMC 1088493.PMID 11516376

3. Anonymous: The World Health Organization. The world health report 1999--making a difference. http://www.who.int/whr/1999/en/index.html

4. Drexler, M: "Secret Agents - The menace of emerging infections" 2002 Joseph Henry Press. http://books.google.com/books?id=nnRuEoynzE4C \&printsec $=$ frontcover $\& \mathrm{dq}=$ Madeline + Drexler + Secret + Agents\&source $=\mathrm{b}$ 1\&ots=0zjYAWOT8c\&sig=HPvLemUlPJJ9O8Rj-ZzXVYI95ic\&hl=en\&ei= 7TiCTb3tKOK30QGd7rTOCA\&sa=X\&oi=book_result\&ct=result\&resnu $\mathrm{m}=3 \& \mathrm{sqi}=2 \& \mathrm{ved}=0 \mathrm{CC} 0 \mathrm{Q} 6 \mathrm{AEwAg} \# \mathrm{v}=$ onepage $\& \mathrm{q} \& \mathrm{f}=$ false

5. Anonymous: Centers for Disease Control and Prevention National Center for Emerging and Zoonotic Infectious Diseases. http://www.cdc.gov/ncezid/. Accessed September 1, 2011. 
6. Karesh W. B., Cook R. A. “The Human-Animal Link”. Foreign Affairs July/ August 2005. http://www.foreignaffairs.com/articles/60821/william-b-karesh-and-robert-a-cook/the-human-animal-link. Accessed September 1, 2011.

7. Anonymous: The World bank: People, Pathogens,and Our Planet Volume 1: Towards a One Health Approach for Controlling Zoonotic Diseases Report No 50833-GLB, 2010 The International Bank for Reconstruction and Development / The World Bank, 1818 H Street, NW Washington, DC 20433

8. Uhlenhopp E.K: Building bridges of One Health. In :Proceedings of Workshop on One Health, Vrdnik 03.-05.03.2014, Serbia

9. Trajković-Pavlović Lj, Popović M, Ilić S, Petrović J: Analysis of elements important for implementation of intergated programs for control of zoonozes and food borne pathogens of zoonozes. In: Proceedings of Workshop on One Health, Vrdnik 03.-05.03.2014, Serbia

Primljeno: 10.12 .2014 .

Odobreno: 29.10.2014. 